\title{
KONFIGURASI DAN TRANSFORMASI KEHIDUPAN AGAMA MENJELANG TINGGAL LANDAS PEMBANGUNAN NASIONAL DI KECAMATAN LEIHITU KABUPATEN MALUKU TENGAH PROPINSI MALUKU
}

\section{Oleh : A. SHADIQ KAWU}

\section{PENDAHULUAH}

Pembangunan yang digalakan pemerintah selama ini, telah menyeba"bkan terjadinya perubahan dalam masyarakat, baik berupa perubahan sosial (social changes) maupun perubahan kebudayaan (cultural changes). Perubahan sosial dapatmencakup perubahan-perubahan dalam struktur sosial atau pola-pola lingkungan sosial, yang antara lain meliputi; sistem status, hubunganhubungan dalam keluarga, sistem-sistem politik dan kekuatan, persebaran penduduk, dan sebagainya. Sedangkan perubahan kebudayaan adalah perubahan-perubahan yarig terjadi dalam sistem ide yang dimiliki bersama oleh para warga, atau oleh sejumlah warga masyarakat yang bersangkutan. Misalnya, menyangkut aturan-aturan atau norma-norma yang menjadi pegangan dalam kehidupan masyarakat, nilai-nilai moral dan agama, teknologi, seni dan estetika, bahasa dan sebagainya. Karena kedua bcntuk perubahan ini senantiasa kait berkait, maka muncullah perubahan-perubahan yang mencakup kedua aspek terscbut, sosial dan budaya.

Di Indonesia, gejala perubahan terscbut ditemukan dalam setiaptahap Pembangunan Lima Tahunan. Begitu pesatnya perubahan itu berlangsung, khususnya pada Pclita VI digambarkan sebagai proses kehidupan yang penuh gejolak, perubahan karena didesak oleh pertumbuhan penduduk, perubahan ekonomi, perkembangan teknologi, persaingan internasional dan perubahan lingkungan hidup.

Oleh karena itu kebijaksanaan pemerintah dalam pelaksanaan pembangunan, bukan saja dapat meningkatkan kesejahteraan hidup masyarakat, akan tetapi akibat sampingan sebagai konsekuensinya bisa saja terjadi di tengah masyarakat. Misalnya, timbulnya suatu era dcpersonalisasi, yang menurunkan dcrajat manusia menjadi bukan lagi manusia. Akibatnya, bukan saja manusia itu berpikir secara tehnik dan eksperimental tetapi juga manusia tidak dapat/tidak mau dianggap sebagai manusia yang bcrtanggungjawab atas akibat dari tindakantindakannya sehingga di samping menjadi abad yang tidak saja hampa, juga menjadi abad yang tidak bcranggungjawab. (Astrid, 1979).

Mengantisipasi kemungkinan terjadinya "abad yang menakutkan" itu, pemerintah telah menerapkan kebijaksanaan pembangunan, baik jangka pendek maupun jangka panjang, yang menempatkan pembangunan fisik material dan pembangunan agama secara bcrimbang. Konsep tiga kondisi ideal, yang meliputi kadar keimanan dan ketakwaan yang tinggi, wawasan keberagamaan yang luas dan matang, dan kerukunan kehidupan agama yang mantap 
dan dinamis, mcrupakan sasaran ideal yang hendak dicapai dalam proses pcmbangunan nasional.

Makalah ini mcrupakan ringkasan hasil penelitian konfigurasi dan transformasi di Kecamatan Lcihitu, Kabupaten Maluku Tengah Propinsl Maluku. Pcnulis akan mcncoba mengcmukakan bcberapa temuan lapangan sebagai jawaban dari beberapa pert any aandasar yang menjadidasar penelitian ini. Pertanyaan-pertanyaan mcncakup: sejauh mana pcranan KUA di Kecamatan, bagaimana institusi-institusi agama tclah bcrubah sebagai dampak pcmbangunan nasional atau modernisasi, bagaimana polapola akulturasi dan inkulturasi agama mclalui pendidikan, bcntuk-bcntuk dan isi dakwah serta jcnis litcratur agama yang masih dibaca dan dianggap pcrlu bagi masyarakat dcwasa ini.

Dcskripsi konfigurasi dan transformasi kclima aspek tcrscbut akan dikcmukakan secara singkat dengan menekankan indikator-indikator umum di scmua desa penelitian. Penelitian ini dlluksunukun solumu sutu bulan dengan bcberapa tahapan. Satu minggu pertama, diadakan penjajakan awal prosedur pcnyelesaian surat-surat administratif, terutama yang bcrhubungan dengan izin di lokasi. Pada tahap ini juga, tim mengadakan kunjungan kc Kantor Wilayah Departcmcn Agama, Sinodc Kristcn, dan menjumpai beberapa informan kunci yang ada di kola Ambon.

Scbclum mengadakan kunjungan resmi ke lokasi dan tinggal di lapangan, tim tcrlebih dahulu menggunakan waklu di Ambon unluk mcmatangkan persiapan penyaringan data. Diskusi kecil semua anggota tim dan menginventarisasi hasil amatan yang dipcroleh. Informasi awal yang diperoleh di kota Ambon ternyata sangat membantu semua personil tim kclika berada di desa penelitian.

Satu-satunya masalah yang dialami adalah pcrubahan lokasi penelitian. Rencana semula, sesuai desain dari Pimpinan Proyek, tim Ambon akan meneliti masyarakat Kristcn di Pulau Haruku Kabupaten Maluku Tengah. Karena beberapa pertimbangan dari Pemerinlah Daerah (Ditsospol), akhi rnya ditcmpatkan di Kecamatan Lcihitu, Kabupaten Maluku Tengah. Dengan perubahan lokasi ini, tim harus mcmulai pendekatan awal lagi, terutama untuk mcngcnal latar bclakang lokasi. Apalagi kcadaan lokasi pertama di Pulau Haruku sangat kontras dengan lokasi yang diinginkan pemerintah Daerah. Kalau di Pulau Haruku sasarannya adalah masyarakat Kristcn Protcstan maka di Lcihitu masyarakat Kristcn Protcstan maka di Lcihitu masyarakatnya adalah pemeluk uguinu Islum yung masih tcrikut dengan tradisi lokal.

Penyaringan data secara efektif dimulai pada tanggal 25 Agustus 1991, selama pcncli tian di 1 aksanakan para peneliti meny ebar di cmpat desa dalam wilayah Lcihitu. Kondisi gcografis dan arus transportasi yang tidak scimbang antara sarana angkutan dcngan konsumen pemakai jasa menyebabkan hubungan antar peneliti terutama untuk pclaksanaan diskusi kelompok mingguan sukar dil aksanakan. Diskusi kecil hanya dapat dilaksanakan secara efektif dengan tiga orang peneliti -yang berdekatan. Namun demikian, hubungan 
koordinasi tetap berlangsung dengan peneliti yang tinggal agak jauh dan terisolir dari pusat kota Kecamatan.

Sesuai ketentuan Pimpinan Proyek, desa yang ditempati adalah merupakan empat desa bertetangga yang dapat dijangkau kendaraan umum. Kriteria metodologis dengan menerapkan pola keberagaam yang rendah, tingkat pengamalan cenderung masih berbaur dengan tradisi lokal. Namun demikian, desa yang dipilih adalah basis komunitas Islam di daratan Pulau Ambon. Sesuai kesepakatan dengan pemerintah kecamatan, maka ditetapkan satu desa di pusat kecamatan, yaitu Desa Hila dan tiga desa lainnya yang berdekatan masingmasing, desa Keitetu, Hitu,dan Mamala.

\section{PROFIL WILAYAH PENELITIAN}

\section{Lokasi}

Kecamatan Leihitu terletak di daratan Pulau Ambon. Dari kota Ambon wilayah ini dapat dijangkau dengan kendaraan roda dua dan roda empat. Jalan yang menghubungkan antarakotaPropinsi Maluku dengan Leihitu sudah beraspal dan hubungan antara kedua daerah itu didominasi kendaraan angkutan umum yang setiap harinya menjalani trayck Ambon - Mamala dan Ambon - Hitu - Hila, seki tar setengahjamperjalanan dengan jarak 41 kilometer.

Kendaraan roda dua masih terbatas. Hal ini nampak di jalan-jalan desa. Penduduk setempat lebih suka berjalan kaki daripada menggunakan kendaraan bermotor. Di Kota Kecamatan Leihitu hanya ada beberapa sepeda motor, satu diantarany a adalah motor dinas milik Camat Leihitu.

Kecamatan ini beberapa di ujung paling
Timur Pulau Ambon yang secara administrative rmasuk dalam wilayah pemerintahan Kabupaten Maluku Tengah. Letak geografisnya membentang di sepanjang pesisir pantai dan bersebclahan dengan Pulau Seram. Sebelah Utara berbatasan Selat Seram, sebelah Barat berbatasan dengan Laut Bum, sebelah Sclatan dengan Kecamatan Baquala dan sebelah Timur dengan Kecamatan Salahutu.

Luas wilayah secara keseluruhan, 258 KM bujur sangkar, pemukiman penduduk pada umumnya terletak dipesisir pantai. Daratan yang menjadi tempat pemukiman dan tanaman-tanaman subur di Kecamatan ini hanya seki tar 18 persen dari luas wilayah secara keseluruhan. Selainnya adalah tanah berbukit 35 persen, gunung-gunung 47 persen dan selebihny a merupakan pertemuan antara dacrah pesisir pantai dengan kaki bukit yang menjolok di sepanjang pinggiran laut.

Pola pemukiman penduduk terkonsentrasi di daerah pesisir pantai. Kebanyakan rumah dlbangun dl sepanjang jalanjalan utama tetapi karena pertambahan penduduk dalam tahun tcrakhir ini, perumahan itu makin mendekati perbukitan. Dataran untuk perumahan makin berkurang schingga letak antar rumah sangat berdekatan.

Pusat desa ditandai dengan jumlah jalur jalan yang lebih banyak dibanding jalur jalan didusun-dusun. Persimpangan jalan yang mcmisahkan rumah-rumah penduduk dalam batas-batas tertentu. Hampir setiap desa mempunyai rumah adat yang bentuk dan ukurannya lebih besar dari rumah penduduk elite desa. Rumah adat ini sekarang berfungsi sebagai kantor desa tetapi ada 
juga rumah adat yang hanya berfungsi sebagai tempat tinggal pejabat dcsa. Tidak semua kepala desa bisa tinggal di rumah adat. Di Hila, misalnya, rumah adat hanya bisa digunakan scbagai rumah pejabat dcsa manakala pejabat dcsa bersangkutan mempunyai hubungan darah dengan klan pendiri rumah adat tcrsebut. Karena yang membangun rumah adat di Hila, adalah klan Ollong, maka hanya kepala desa dari klan itulah yang bcrhak tinggal di rumah adat desa.

\section{Administrasi pemerintahan}

Sccaraadmini strati f, Kecamatan Lcihitu tcrdiri dari 16 desa dan 34 dusun. Kecamatan ini belum mcmiliki kelurahan termasuk desa di pusat kecamatan. Sclain pemerintahan desa dan dusun, ada juga yang discbut petuangan, yaitu dcsa tradisional yang mempunyai scjarah tcrsendiri dalam proses penyebaran Islam di Pulau Ambon.

Informasi tcntang asal usul dacrah ini, tcrutama yang berhubungan dengan periodisasi pemerintahan sangatbervariasi. Salah satu sumbcr yang dapat dipegang, walaupun masih perlu sclcksi, adalah naskah hikayat tanah Hitu, yang dialihbahasakan dan ditranskripsi olch Manusama, seorang pendcta di Saparua.

Dalam naskah ilu diccritakan bahwa sistcm pemerintahan formal di wilayah Leihitu, sudah ada scbelum masuknya bangsa Portugis. Waktu itu, ada empat perdanayang mcmegangsatu wilayah terotcrial, dan sifatnya otonom. Masing-masing perdana bertanggungjawab pada satu ikatan konfederasi. pcrdana ini adalah (1). Sapolc zaman jadi bcrgclar totohatu, (2) Waipalili atau zaman mulai bergelar tanihitumesen, (3). Jamilu, bergelar lating atau nustafi, dan (4). Kiyai pati, bergelar Ollong atau pati tubang. Konfederasi empat perdana ini, diikat oleh perjanjian mufakat dengan ikrar : "itulah seperti emas tiada dengan sepuhnya lagi."

Di scluruh bagian pesisir Utara dan Timur Pulau Ambon pada waktu itu, termasuk dalam ikatan federasi ini. Sistcm ini berkembang kctika wilayah perdana mereasakan perlunya mcmperkuat wilayah mereka dengan ikatan yang lebih ketat. Oleh karena itu, kecmpat perdana kemudian sepakat mcngangkat seorang raja. Menurut bebcrapa informasi di Hila dan Hitu, Raja yang pcrtama diangkat pada waktu itu, adalah Latusinatia. Bcrsamaan penetapan raja, ditctapkan pula dalam struktur pemerintahan seo rang haki $m$ yang be rtugas untuk menyclcsaikan kasus scngketa, di wilayah empat perdana tadi. Hakim pertamadiangkat seorang tokoh bernama Abubakar Nasidiki.

Kemudian terjadi proses perubahan wilayah pcrdana menjadi semacam "desa" pada tahun 1599, yaitu kctika Belanda masuk kc wilayah ini. Scbelum adanya istilah "dcsa", wilayah-wilayah tersebut masih populcr dengan "negeri". Sampai sekarang, istilah negeri masih populer dan jabatan kepala desa masih diidentikan dengan raja.

\section{Kependudukan dan mata pencaharian.}

Hinggapcrtengahan tahun 1991,jumlah penduduk di Kecamatan Leihitu, 54.664 jiwa. Tcrdiri dari 10.169 kepada keluarga. Penduduk ini terscbar di 16 buah desa, masing-masing; Hila, Seith Negeri lama, Urcng, Assilulu, Larikc, Wakasihu, Allang, 
Liliboy, Halu, Hitu lama, Hitumeseng, Mamala, Wakal dan Morcla.

Dibanding jumlah penduduk dengan potensi sumber daya alam yang besar, diperkirakan masih banyak sumber daya yang belum dieksploilasi oleh masyarakat. Sektor perikanan misalnya, masih ditangani secara sederhana dan bersifat subsistensi, dibanding upaya-upaya baru untuk mencoba menggunakan teknologi baru dan menjadikan sektor perikanan ini sebagai mata pencaharian yang bersifat komersial. Walaupun pemukiman penduduk terkonsentrasi di pesisir pantai, sektor perikanan belum mendapat penanganan yang intensif, sehingga sektor itu masih tetap menggunakan teknologi tradisional dengan hasil tangkap yang relatif terbatas.

Penduduk Leihitu nampaknya lebih tertarik pada sektor pertanian dibanding perikanan. Seperti halnya dengan laut yang kaya dengan sumber daya alam, tanah di Leihitu juga sangat subur. Tanaman bernilai ekspor, -seperti cengkeh dan pala, tumbuh subur dan dapat ditemukan dimana-mana. Tanaman rempah-rempah ini, dapat ditemukan mulai dari pesisir pantai sampai ke puncakpuncak gunung. Selain cengkeh dan pala, sagu yang menjadi makanan pokok penduduk desa juga tumbuh subur di seluruh wilayah Kecamatan.

Demikian pula hasil pertanian seperti jagung, ketelapohon, ubi jalar, kacang tanah dan buah-buahan. Masyarakat Leihitu, mempunyai tradisi gotong royong yang sangat positif untuk mendapatkan nilai ekonomi tambahan. Misalnya saja, rumah tangga yang bcrdckatan, akan saling bekerjasama untuk mcmetik cengkeh pada waktu panen. Kerjsama ini harus dilakukan ber- gantian, karena panen cengkeh masingmasing keluarga berbeda waktunya. Dengan demikian kalau semua anggota rumah tangga yang berdekatan mempunyai kebun cengkeh, maka waktu panen harus dijadwalkan, supaya mereka secara bergiliran dapat saling membantu untuk memetik cengkeh tetangga. Kerjasama ini bukan semata-mata sekedar saling membantu tetapi diantarakelompok ini ada imbalankerja yang akan diberikan berupa cengkeh kepada setiap orang yang terlibat dalam pemetikan itu. Pembagian upah ini, bersifat longgar dan tidak ada pedomannya. Jumlah imbalan jasa dari seorang pemilik cengkeh kepad pemetiknya, tergantung pada kemauan pemiliknya. Tetapi, ada kecenderungan, bahwa anggota keluarga yang ikut dalam panen, akan mendapat bagian yang lebih besar dibanding dengan pemetik lainnya yang bukan anggota keluarga. Demikian pula, bagian tetangga terdekat biasanya akan lebih banyak dibanding dengan tetangga yang letak rumahnya lebih jauh dan tidak mempunyai hubungan kekeluargaan dengan pemilik cengkeh.

Pola kegiatan ekonomik masyarakat ditentukan berdasarkan potensi sumber daya. Pemasaran cengkeh, pala dan hasil pertanian lainnya, terutama yang diproduksi dalamjumlahbesardisalurkanmelaluiKUD. Pcngelompokan petani dalam KUD merupakan kerj asama yang menguntungkan para petani. Dengan cara ini juga, petani dapat mcnghindar dari jcbakan para rentenir yang mencari keuntungan sepihak tanpa mempcrhitungkan kerugian petani.

Selain bckerja sebagai nelayan dan petani, ada juga penduduk Leihitu yang bekerja sebagai pegawai negcri, pengrajin dan 
mata pcncaharian lainnya, seperti pcngusaha dan sopir angkutan umum, wiraswasia, tetapi pcrsentase dari kclompok ini sedikit dibanding dengan jumlah yang menckuni pekcrjaan sebagai pctani dan nclayan.

\section{Penggolongan dan pelapisan sosial}

Pelapisan sosial di Kecamatan Leihitu, tidak secara baku dan eksplisit terungkap dalam sistcm sosial masyarakat, khususnya pelapisan berdasarkan keturunan. Tingkat sosial mclingkar pada fungsi dan peran yang dimainkan oleh scseorang sepcrti Raja, para pemuka adat, kcpala-kcpala soa dan scmacamnya, pada level atas, dan dibawahnya adalah rakyat.

Istilah bangsawan dikailkan dengan tradisi rekruitmen pemimpin desa dari keturunan tertentu semata buka berdasarkan jenis "darah" scbagaimana tradisi kepemimpinan pada bcberapa klan di Kcitctu. Pelapisan sosial mulai bergescrdari "pcran bangsawan" kc akumulasi peran dan kharisma. Dewasa ini, strata hamba alau kclompok lapis bawah dalam pelapisan sosial sudah tidak dikenal lagi dalam masyarakat. Strata itu kini digantikan dengan "rakyat", tctapi pcran dan fungsinya jauh lebih tinggi daripada "hamba" dalam stratifikasi tradisional.

\section{TEMUAN HASIL PENELITIAN}

\section{Pendidikan agama}

Lcmbaga pendidikan formal yang menyelenggarakan pendidikan agama di Leihitu, adalah Tarrian Kanak-kanak, SDN, SLTPN dan SLTAN. Selain itu, ada sebuah pesantren yang bcrlokasi di Desa Hila, yang dikelola Yayasan Jcmbatan Jasa Ambon.
Sebuah madrasah setingkat Ibtidaiyah di Desa Hila juga pernah bcrfungsi padazaman pendidikan Jcpang. Madrasah ini didirikan oleh tiga orang mubalig, yaitu : Ahmad Bahsoan, Ahmad Hatala, dan Ahmad Hui. Madrasah ini bisa bcrtahan selama enam tahun dan dalam kurikulumnyamenerapkan seratus perscn matcri pendidikan agama. Waktu belajar pada sore hari. Hal ini maksudnya agar murid-murid sekolah dasar yang belajar di waktu pagi dapat mongikuti pelajaran agama di waktu sore pada madrasah ini. Sayang sckali, usia madrasah ini bcrakhir sclclah ketiga pendirinya meninggalkan Hila.

Dalam pendidikan formal, khususnya di SDN dan SMPN, penyajian mata pelajaran agama sangat rendah. Di SMP Hila-Keitetu saja, penyajian mata pcajaran agama sangat rendah. Di SMP Hila-Keitetu saja, penyajian mata pelajaran agama mendapat porsi duajam pelajaran perminggu, demikian pula di SDN, kecuali untuk kelas 4,5 dan 6 masing-masing mendapat porsi 3 kali scminggu. Dibanding mata pelajaran lainnya, porsi mata pelajaran agama dinilai tidak cukup, sehingga pcrlu, dipertimbangkan frekwensi penyajiannya atau bobot satuannya yang scimbang kedudukannya sebagai mata pelajaran urutan pertama, dalam pembcrian prcstasi murid lewat buku rapor. Di pihak lain amat tcrasa, semakin beratnya tantangan moral murid-murid dewasa ini. Khusus di SMPN, pengembangan wawasan kcagamaan siswa dinilai kurang mampu distimulasi tanpa melakukan metodemctodc diskusi, sebagaimana tertuang dalam buku pedoman pengawasan penilaian dan pembinaan kependidikan yang dikeluarkan Kanwil Dikbud Propinsi Maluku (1991). 
Pelaksanaan pendidikan agama di sekolah bukan saja tergugat dari sudut kelayakan proporsi jam pelajaran akan tetapi juga dari faktor lain. Di Keitetu, sejak tahun 1980/1981 tidak ada guru agama pemerintah di SDN, sementara di Hila, Hitu dan Mamala, ada satu dua guru agama, dengan frekwensi jam pelajaran dan jumlah kelas yang tidak berimbang. Di sekolah yang tidak mempunyai guru agama, materi pelajaran agama terpaksa dibawakan oleh guru kelas untuk mengantisipasi kepincangan tersebut. Hal ini menyebabkan adanya kctidaktepatan dari, segi kurikuler, juga dari segi metodologis. Guru kelas lebih banyak menggunakan ceramah yang terpokus pada pembinaan anlak, sesuatu yang dianggap paling enteng, dilihat dari kapasitas guru kelas, tanpaharusmembuat satu an pelajaran. Selain itu pokok bahasan juga berputar pada bidang ibadah praktis seperti sholat.

Di sekolah menengah, baik tingkat pertama (SLTP) dan SLTA proses belajar mengajar bidang study agama sedikit lebih baik. Penyajian materi pelajaran berlangsung sesuai waktu yang telah dialokasikan. Ditambah lagi dengan kegiatan co-kurikuler seperti praktek sholat, menulis dan menghafal ayat-ayat dan doa-doa tertentu, serta membentuk kelompok kasidahan. Evaluasi dilakukan melalui tahap formatif (setiap selesai penyajian materi) dalam bentuk lisan dan tulisan, sub sumatif (setiap 2-3 kali pertemuan) dan sumatif (bulan).

Pendidikan agama non pemerintah yang dikelola oleh masyarakat, yaitu madrasah dan pesantren. Di dua desa bertetangga seperti Hila-Keitetu, pendidikan jenis madrasah ini, sudah dikenal. Selain trio mubalig yang mendirikan madrasah di Hila pada zaman pendudukan Jcpang, ada juga sebuah madrasah yang dibangun masyarakat atas prakarsa KH Muhammad Nur. Madrasah mulai berfungsi pada 1927 dan 1953. Sekalipun kurun waktu itu kegiatan madrasah ini pernah terputus, karena pengasuhnya KH Muhammad Nur meninggalkan Hila, dan berangkat ke Balikpapan untuk menambah pengetahuan agama.

Peranan KH Muhammad Nur, bukan saja populer dai Keitetu, tetapi, figur ini adalah profil seorang ulama serba bisa yang pernah dimiliki seluruh jazirah Hitu (Kecamatan Leihitu). Ia memiliki wawasan kcilmuan yang luas, bukan saja ilmu agama Islam (Nahwu, shorof, hadis, tafsir, dan fiqh), seperti juga ilmu-ilmu lain, yang cenderung dikategorikan sebagai pengetahuan umum, misalnya ilmu mantiq, falaq, dan acuhd. Beliau juga menjadi rukukan berbagai masalah yang berkaitan dengan masailuddiniyabagi masyarakat di Kecama$\tan$ Leihitu.

Pendidikan pesantren, terdapat di Kota Kecamatan. Pesantren Darul Argam, dikelola oleh Yayasan Jembatan Jasa yang pusat aktivitas pengurusnya ada di Ambon. Pesantren ini mengelola tiga tingkat pendidikan formal, yaitu, Raudhatul Atfal (Tarn an kanak-kanak), Madrasah Ibtidaiyah (selingkat SD), dan Madrasah Tsanawiyah (setingkat SMP). Di tingkat Tsanawiyah, buku-buku pedoman yang dipergunakan bervariasi menurut bidang study. Umumnya, kurikulum pesantren terfokus padamata pelajaran agama, dan tidak memberikan materi pelajaran yang bersifat umum. Pada 
mulanya, pengasuh Pesantren Darul Argam, mewajibkan pemakaianbahasa Arab dalam proses belajar mengajar, tetapi akhirakhir ini, pihak guru pesantren sudah diizinkan untuk menggunakan bahasa Indonesia sebagai bahasa pengantar selain bahasa Arab. Namun izin itu masih berstatus "pelengkap", karena pemakaian bahasa Arab masih tetap diwajibkan.

Selain madrasah dan pesantren, masyarakat juga menyelenggarakan pengajianpengajian lokal. Pengajian anak-anak dikclola anggota masyarakat secara pribadi. Dan pengajian dalam bentuk majlis taklim, pengkajian agama, tahlilan dan acara barzanji, tersebar di semua desa penelitian, sebagai spesifikasi desa-desa di Lcihitu. Karakteristik pengajian ditandai tidak adanya kurikulum yang baku, jumlah murid tidak tetap dan waktu pclaksanaannya disesuaikan kcadaan serta persyaralan administrasi tidak mengikat. Kondisi terscbut disebabkan oleh sifat kegiatan itu yang sebenarnya tidak lain dari pengajian dasar Al-Qur'an yang diperluas. Selain diberikan pelajaran dasar Al-Qur'an, pesertadidikjuga diberikan pengetahuan tentang tatacara taharah dan sholat serta doa-doa. Komposisi dan pengaturan pclajarannya tcrgantung pada sclera scorang guru. Tujuan utamanya, agar peserta didik memiliki pengetahuan praktis tentang bidang-bidang terscbut. Padaumumnya, guru mengaji menggunakan metodc tradisional model bagdady, dimana pertama-tama peserta diajarmengcnal huruf hijaiyah. Proses itu diulang-ulang, hingga mencmpuh waktu sampai enam bulan, bahkan satu tahun.

Kegiatan yang dapat mcmupuk cmosi kcagamaan dan mcningkatkan kemampuan membaca adalah pcrkumpulan berzanji. Perkumpulan ini merupakan tradisi khususnya bagi kaum wanita baik melalui wadah PKK maupun melalui kelompok yang khusus di bentuk untuk itu. Kegiatan membaca berzanji dilakukan satu sampai $3 \mathrm{kali}$ dalam seminggu, bergilir dari rumah ke rumah anggota. Banyak remaja putri yang bergabung karena selain dapat memperlancar kemampuan membaca tulisan Arab juga mengandung unsur seni dengan irama kasidahan khas lokal. Mated yang dibaca dan dilagukan, adalah berzanji itu sendiri Syarful anam, dan Dibag. Ketiganya terkandung dalam berzanji dalam berzanji itu sendiri.

\section{Dakwah Agama di Masyarakat}

Kecamatan Leihitu dengan empat desa penelitian pada hakekatnya adalah, merupakan konfigurasi dari pola kehidupan tradisional dalam beragama. Salah satu indikatornya adalah tidak adanya organisasi dakwah yang khusus menangani kedakwahan secara programatis dan sistimatik. Di kota kecamatan mcmang ada organisasi MDI (Majlis Dakwah Islamiyah) tetapi organisasi ini tidak fungsional, cenderung bersifal formalistik, dan sering digunakan untuk melcgitimasi status pengurusnya dalam strata sosial yang baru.

Untuk mcngetahui bagaimana kegiatan dakwah berlangsung dapat dikemukakan beberapa bentuk kegiatan dakwah yang umum berlangsung di desa-desa penelitian.

\section{a. Khutbah Juin'at.}

Khutbah Jum'at dipandang sebagai bagian dari sholat Jum'at itu sendiri, sehingga harus dilakukan sesuai ketcntuan 
yang mampu. Ada juga sesajen yang turut dihidangkan tetapi tidak boleh dimakan, karena diperuntukkan bagi arwah almarhum. Dalam acara hari kctujuh, diadakan tahlilan dan khataman Al-Qur'an.

c. Mattampung (pemasangan batu nisan). Pada hari kecmpatpuluh setelah mcninggal, keluarga mengadakan upacara dengan mengundang scluruh keluarga dan tetangga scrta sahabat. Pada acara ini dilakukan tahlilan dan scsudah tahlilan, pihak keluarga datang kekubur untuk menanam batu nisan. Diantara acara yang berkaitan dengan kematian, mattampung adalah upacara yang paling ramai dilaksanakan olch keluarga. Upacara lainnya adalah pcringatan hari keseratus dan acara haul (Bugis : maltemmu taun) pada waktu cukupsatu tahun mcninggalnya Almarhum.

Scmua acara yang dilakukan untuk kematian, imam desa atau imam dusun scrta perangkat syara' memegang peranan, karena tujuannya adalah mendoakan almarhum.

\section{HI}

Pembauran antara kepercayaan lokal yang bersifat tradisional dengan ajaran Islam masih mcwarnai nilai-nilai yang dianul masyarakat Desa AllamungengpatuE Kabupaten Bone, yang pada umumnya menganut Agama Islam.

Aspek-aspek keagamaan dalam kehidupan sosial masyarakat, adalah menjalin hubungan dengan Allah Tuhan Pencipta dalam bentuk ibadah serta pelaksanaan upacara-upacara daur hidup, upacara tolak bala dan upacara keagamaan.

Dalam kehidupan sehari-hari, masyarakat masih terikat sistem norma dan adat yang masih diindahkan dan dipatuhi, dan dalam kehidupan beragama, mcreka mcnggantungkan diri pada tokoh agama dan pemimpin mereka.

\section{Saran-Saran :}

Dalam masyarakat Desa Allamungeng PatuE Kab. Bone masih banyak ditemukan nilai-nilai dan tradisi yang menjadi kebudayaan yang dapat dikembangkan dalam rangka membentuk menusia yang utuh, schingga kondisi kultural masyarakat akan lebih bennakna sebagai potensi pembangunan.

Upacara-upacara tradisional hendaknya diwamai dengan ajaran Islam, untuk itu pcrlu adanya bimbingan dakwah yang mampu mengajak masyarakat untuk bertindak lebih rasional. Maka partisipasi aktif pemuka agama dibutuhkan untuk mclestarikan kebudayaan disertai peningkatan ketakwaan tcrhadap Tuhan Yang Maha Esa. 
dengan pembacaan Al-Qur'an dan tahlilan. Selain itu upacara yang sama juga dilakukan pada saat-saat hajatan, dan setiap malam Jum'at di rumah seseorang yang sedang menunaikan ibadah haji.

Berkas-berkas mapannya proses dakwah masa lampau juga terlihat dalam bidang kcscnian yang diwarnai oleh nafas Islam seperti tari gambus pada acara khitanan, perkawinan, tari sawat untuk penjempulan tamu dan yang paling populer adalah hadrat dilakukan sepanjang bulan puasa, sesudah sholat tarwih sampai makan sahur kcliling kampung, dan mengiringi upacara arakan hewan kurban pada musim haji. Hal-hal yang tertinggal dari masa lampau yang dari segi dakwah masih dapat diharapkan andilnya dalam pcmupukan tradisi simbol keagamaan dan sampai dimana mampu bcrtahan bcrhadapan dengan perkcmbangan kesenian sekarang terutama band dan orkes, masih perlu dilihat transformasi dan dialektikanya.

\section{Lektur Agama}

Sulit diharapkan adanya lektur keagamaan yang mengisi rumah-rumah penduduk, demikian pula kecenderungan bclajar agama dan pusat-pusat pelajaran agama sangat minim, bahkan tidak ada di desa itu.

Lektur yang paling populer adalah berzanji disamping Al-Qur'an. Lebih dari kandungannya yang memuat kisah Nabi. Berzanji memikul beban nilai yang cukup berat karena hampir segala aktivitas dan saat kritis yang dialami penduduk desa baik sebagai pribadi maupun kolektif sclalu dikaitkan keberkatannya lewat pembacaan berzanji. Sedang Al-Qur'an sebagai Kitab
Suci, dibaca pada waktu tertentu (malam Jum'at) mengiringi peristiwa kematian dan dalam bulan ramadhon, khususnya surahsurah tertentu, seperti Yasin yang dianggap mengandung khasiat tertentu.

Legitimasi historis itu merupakan simbol keterikatan masyarakat Leihitu terhadap lektur Al-Qur'an dan Berzanji, yang secara tradisional dipertahankan. Demikian juga dengan kitab-kitab klasik yang lain disimpan dan cenderung diistimewakan kedudukannya, seperti Kitab Al Idha fil Figh, milik KH Muhammad Nur di Keitetu. Buku ini bertulisan tangan dengan tinta hitam dan terbungkus dengan kain bersama beberapa gulungan naskah khutbah dalam potongan bambu.

Konscntrasi pelaksanaan tugas keagamaan pada diri Imam dan aparatnya merupakan salah satu faktor kurang tertariknya masyarakat mcmpelajari agama secara pribadi dari lcktur-lekturpopuler. Buku yang dilemui di seluruh desa penelitian, hanya yang bcrkaitan dengan pelaksanaan tugastugas praktis. Namun demikian, ada beberapa lektur yang ditemukan di rumah aparat masjid, seperti: Kumpulan khutbah Jum'at oleh Drs. Syaminan Zaini, 1981, Pedoman Khutbah Jum'at Dari Masa ke Masa oleh Ustaz Mahfudli Sahli, Khutbah Jum'at oleh Yunan Nasution, Kumpulan Khutbah Jum'at Pilihan, 1981, Khutbah Jum'at Satu Tahun mengisi Aqidah Islam oleh K. Amin. Kumpulan Khutbah Jum'at oleh Bey Arifin. Selain itu ada buku saduran, seperti Kitab Furkunan karangan H. Abd. Rasyid Banjir disadur dari buku Syekh Muhammad Arsyad Banjar. Ratib Hadad, buku yang berizi zikir dan doa dinukilkan dari Sayyid Abdul- 
lah bin Abibakar bin Husain Assegaf, Ambon.

"Kitab Suci Al-Qur'an dalam berbagai bentuk cetakan, seperti yang diterbitkan Al Maarif Bandung, Al-Qur'ah dan terjemahannya, terbitan Departemcn Agama, dan Surah Yasin ukuran saku. Al-Qur'an ini selalu didapati di rumah-rumah penduduk dan di masjid-masjid.

\section{Organisasi keagamaan}

Salah satu organisasi keagamaan, yang merupakan warisan dari zaman kerajaan di Leihitu, adalah organisasi kepenghuluan. Struktur organisasi ini, terdiri dari Imam (satu orang), khatib (dua sampai tiga orang), modin (dua sampai tiga orang), dan marbut (satu orang). Imam bertugas sebagai imam pada setiap sholat jamaah, khatib untuk membacakhutbah, modim sebagai muazzin, dan marbut, mengurusi kebersihan dan keamanan masjid. Penghulu bertanggungjawab tcrhadap penyelenggaraan peribadatan di dalam masjid, sedangkan kegiatan yang berkaitan dengan rehabilitasi atau pembangunan masjid merupakan tanggungjawab raja dan adat. Kepanitiaan dalam pengelolaan masjid sebagaimana didapati di tempat lain, tidak dikenal di wilayah ini.

Untuk menelusuri proses transformasi pola kepemimpinan dan keumatan masyarakat tidak dapat dipisahkan dari variabelvariabel yang telah mempengaruhi proses perubahan tersebut. Seperti diketahui, bahwa proses perubahan secara makro di wilayah ini, paling tidak disebabkan dua hal. Pertama, faktor dari dalam, yaitu berubahnya (bergesernya) komitmen masya- rakat terhadap lembaga dan organisasi yang ada (organisasi penghulu dan organisasi masjid tradisional). Kcdua, adanya faktor dari luar, yaitu terjadinya pergeseran sikap dan persepsi masyarakat terhadap organisasi agama yang dibangun sebelumnya. Faktor pertama, bergesernya komitmen terhadap lembaga-lembaga keagamaan tradisional, seperti peranan organisasi adat (uhusallua). Organisasi ini, sebenarnyalepas dari struktur organisasi penghulu. Karena, mempunyai tanggung jawab sepenuhnya untuk mengawasi dan menjaga masjid. Pada saat ini kclompok tersebut mulai diintegrasikan ke dalam organisasi penghulu, namun jangkauannya sudah mulai bergeser dari hanya untuk tugas-tugas kemasjidan, menjadi tugas agama dalam skala yang lebih besar. Keterikatan kcpada masjid, menjadi simbolik dan oleh karena itu masjid adalah ungkapan simbolik untuk menggambarkan agama secara makro.

Namun demikian, organisasi ini tidak berkembang sebagaimana mestinya. Mcskipun sudah bisa diakomodasi melalui pengembangan fungsi-fungsi keagamaan yang lebih besar, tetapi penangkatan personil baru yang bcrtolak dari pertimbangan geneoogis dan bukan pertimbangan keahlian menyebabkan organisasi ini tidak dapat berkembang sebagaimana mestinya.

Indikator semakin tajamnya pemisahan jamaah pria dan wanita, juga menunjukan bahwa organisasi agama lokal sudah tidak mampu lagi mengatasi perpecahanperpecahan yang terjadi di kalangan umat, dan semakin rapuhnya faktor-faktor integratid yang pernah dominan di seluruh jazirah Hitu. 
Walaupun ada organisasi lain, seperti PHBI dan institusi KUA sebagai ujung tombak Depag di kecamatan, organisasi ini secara struktural tidak mempunyai massa. Ada kecenderungan masyarakat menganggap bahwa organisasi tersebut sebagai media pemerintah dibanding sebagai forum inventarisasi keinginan-keinginan dari masyarakat bawah. Majlis Dakwah Islamiyah juga kurang populer, karena orientasinya dianggap terlalu vokal dalam masalah-masalah politik.

Pada dasarnya, masyarakat Leihitu membutuhkan organisasi independen yang dapat menjembatani aspirasi kcagamaan masyarakat dengan kebijaksanaan pemerintah. Demikian pula kepemimpinan yang dibutuhkan bukan masalah formal atau tidaknya akan tetapi bagaimana semua kebutuhan masyarakat tcrmasuk penyuluhan keagamaan yang relatif terbatas bisa tcrpenuhi.

\section{KESIMPULAN DAN SARAN}

Kcsimpulan utama yang mcrupakan hasil penelitian, yaituterjadinyatransfomiasipada scktor kehidupan kcagamaan, disebabkan perkembangan masyarakat dalam bebcrapa dekade. Faktor-faktor penyebabnya antara lain karena wilayah Leihitu secara gcografis di daerah sepanjangpesisirpanlai telah lama mengadakan kontak secara intensif dengan bangsa-bangsa lain (Portugis, Belanda, maupun dengan bangsa-bangsa lain (Portugis, Belanda), maupun dengan pendatang yang berasal dari komunitas budaya yang lain.

Kontak dengan pendatang barat, di mulai sejak abad yang sangat lama ketika negcrinegeri di Pulau-pulau ini, dengan kckayaan dan sumber alam potensial, didatangi pc- dagang barat yang mengeruk keuntungan dari hasil rempah-rcmpah di daerah ini. Karena itu pula, hampir sepanjang abad negcri-negeri ini terjebak dalam konflik yang panjang dan keras, serta meminta banyak korban. Kedatangan bangsa-bangsa barat dengan politik "pecah belah" meretakkan ikatan tradisional, seperti pela yang pemah mantap.

Persepsi masyarakat terhadap agama, selalu berada dalam pusaran agama kontekstual, bcrcampur dengan tradisi. Umat Islam selalu berjuang melawan penjajah. Mercka berada dalam kondisi-kondisi yang mengharuskan untuk memupuk kekuatan dengan cara apa saja. Tcrmasuk, mcramu kcmbali kepcrcayaan agama dalam ikatanikatan tradisional yang sarat dengan mistik. Usaha mengembalikan masyarakat kepada kepcrcayaan tcks, masih menghadapi banyak masalah karena sistem pemahaman terhadap agama kontckstual tadi sudah bcrjalan mapan. Dalam hal ini, mudah muncul kelompok-kclompok agama lokal yang berusaha memapankan eksistensi kclompoknya dengan mensistimatisasikan kegiatan-kegiatannya, kelompok berzanji tahlilan, adalah salah satu contoh dari kasus ini.

Sebagai saran, scbaiknya pranata tradisional dapat dikembangkan dan diakomodasi dengan siruktur organisasi yang lebih rasional dan programatis. Usaha kearah ini hany a akan tercapai $m$ anakala ada kerjasama antara pemuka adat, agama dan pemerintah desa, sebagai pewaris dari struktur lama. Demikian pula, penambahan jumlah personil Depag di Kecamatan dan kalau mcmungkinkan bisa di bentuk Kantor Perwakilan KUA di dacrah-dacrah terpencil yang terisolasi dari pusat Kecamatan. 


\section{DAFTAR PUSTAKA}

Kuntjaraningrat, Masyarakat Desa di Indo-

nesia, Universitas Indonesia, Jakarta. 1962

Paeni, Muchlis, ed, Teknologi dan kehidupan sosial di Kawasan Pantai, P3MP Universitas Hasanuddin, Ujungpandang.

Wayner, Myron, ed, Modernisasi, Dinamika Pertumbuhan, Universitas Gajah Mada, Yogyakarta. 1977
Shadiq Kawu, dkk Konfigurasi dan Transformasi Kehidupan Agama menjelang tinggal landas pembangunan nasional di Kecamatan Sentani, Irian Jaya Badan Litbang Agama. 1991

Cooley, I Frank, Mimbar dan Tahta, hubungan lembaga-lembaga keagamaan dan pemerintahan di Maluku Tengah, Sinar Harapan, Jakarta. 1987

Syafii, Ahmad, ed, Konfigurasi dan Transformasi kehidupan Agama di Indonesia, Tahap I, Badan Litbang Agama. Jakarta. 1991 